Original Article (short paper)

\title{
Maracanã stadium: place of carioca sport
}

\author{
Ana Beatriz Correia de Oliveira Tavares ${ }^{1}$ (D), Silvio de Cassio Costa Telles ${ }^{2,3}$ (D), Sebastião Josué Votre ${ }^{4}$ \\ ${ }^{I}$ Instituto Federal de Educação, Ciência e Tecnologia do Rio de Janeiro, IFRJ, Rio de Janeiro, RJ, Brazil; ${ }^{2}$ Universidade \\ do Estado do Rio de Janeiro, UERJ, Rio de Janeiro, RJ, Brazil, ${ }^{3}$ Universidade Federal do Rio de Janeiro, UFRJ, \\ Rio de Janeiro, RJ, Brazil; ${ }^{4}$ Centro Universitário Augusto Mota, UNISUAM, Rio de Janeiro, RJ, Brazil
}

\begin{abstract}
Aims: This study addresses the relationship between fans and the location of sport, focusing on the soccer stadium located on the right margin of the Maracanã River, in the city of Rio de Janeiro. The objective is to analyze the practices and behaviors adopted by fans in the Maracanã stadium and to discuss the relation they have with the architecture of the stadium throughout its history. The study contributes to the construction of representations of this place, which is the symbol of soccer in Rio de Janeiro. Methods: Based on the concept of oral history, the data was drawn from two in-depth interviews with elite interviewees and also documents from the Sports Superintendency of the State of Rio de Janeiro (SUDERJ) archives. Results: The analysis, being of both a descriptive and qualitative character, innovate in the discourse analysis of the collective subject and incorporates Yi-Fu Tuan's ideas of 'space' and 'place' in a relevant and necessary analysis of the changes undergone by the stadium. Conclusion: The study allows for the interpretation and preservation of perceptions and representations about experiences undergone by the majority of the fans, who contributed to the transformation of the old Derby Club into the place for Carioca soccer.
\end{abstract}

Keywords: soccer; space; place; Maracanã Stadium; symbol.

\section{Introduction}

The importance of soccer in Brazilian culture can be translated in part by its imposing stadiums, that serve as places of great festivity and have great symbolic value. The stadiums are responsible for bringing together thousands of fans in search of sports-related emotion. Modern arenas, which are spread throughout Brazilian cities, are representative of different phases of soccer. These stadiums provide diverse experiences that can be modified depending on the scenarios presented to fans.

These modifications, which are suffered by the stadiums, accompany the social configurations of each time period and dislocate both the architectural structure and space's characteristic behaviors and practices to the field of memory, which ceases to exist. In a bid to recover traces of a national symbol in Brazil's soccer scenario, we have elected to make the old Maracanã into the object of this study.

The stadium was inaugurated in 1950 and underwent its largest structural alteration in 2010 in order to meet FIFA's international requirements and host Brazil's 2014 World Cup. According to Gaffney ${ }^{1}$, the restructuring imposed by the megaevents involves a large area. Maracanã would be the center of what the author calls "sporting constellations", a group of transformations in space and on the flow systems that connect them. A stadium goes far beyond the simple material form and is important because it 'represents and reproduces the social structures and material practices that surround it (p.26).

Specifically at Maracanã, what would be an adequation reform ended up being an almost complete demolition, maintaining the external facade and the monumental ramps. On the inside, an entirely new stadium that brought new practices, behaviors, and a wistful feeling from fans.

Regarding space/place discussions, we have used the ideas of humanistic geographer Yi-Fu Tuan, who seeks to understand the "human world" by studying the relationships of people with nature, $[\ldots]$ as well as their feelings and ideas"2 (p.143), regarding the contexts in which they act and live. The author works with the concepts of "space" and "place" in bipolar distribution, and designates "space" as a dark, unknown and unfamiliar environment, while "place" is the clear and known atmosphere with significant symbolic relevance, as much for the individuals as for the social groups who, in it, construct their feelings. Therefore, space and place are constructed and "re-signified" from their experiences, in a dynamic and cumulative form, so that space becomes a place to acquire definition and symbolic significance, and vice-versa. Thus, a given territory returns to a condition of common space when it loses its symbolic value for the groups that use it. Positive emotional experiences appear in the construction of pertinent symbols and in identification. "Experience implies the capacity to learn from one's own existence" ${ }^{\prime 3}$ (p.9).

We welcome Mello's postulations, related to the relevance of an object as a point of concentration or central area, that offers goods and services to the population. "Central places attract users and radiate ideas and meanings"4 (p.23).

The soccer stadium, which is considered sports equipment, then becomes a central place, which leads to territorial transformations that modify the urban landscape. They are visible monuments that become symbolic objects to individuals. According to Mascarenhas", "the stadiums, with their 
importance and physical and temporal circularity [...] unique and distinct place of collective meetings and rituals that are periodically repeated hold, for a true fanatic, some resemblance to sanctuaries". (p. 6).

Vertinsky and Bale ${ }^{6}$ collaborate with the idea of a sacred place. This is a feeling that is born with the architectural project and undergoes every event/ritual that happens inside a stadium, building a social memory that is responsible for the construction of a feeling of collective belonging, which attributes meanings to the place.

O estádio de futebol, considerado um equipamento esportivo, torna-se então um lugar central que implica transformações territoriais que modificam a paisagem urbana. São monumentos visíveis que se tornam objetos simbólicos para os indivíduos. Segundo Mascarenhas (1999), "os estádios, com sua imponência, circularidade física e temporal, (...) lugar distinto e único de encontro coletivo e ritualizações que se repetem periodicamente, guardam, para o torcedor fanático, algumas semelhanças com os santuários." (p.6).

It was in search of these meanings and ideas about an emblematic stadium that no longer exists in its initial configuration and that is a part of many fans' history that we drew up the objective of analyzing the practices and behaviors adopted by fans in the Maracanã Stadium and discussing their relationship with the stadium's architecture throughout its history.

We understand as fan practices their behavior according to the cultural constructions established through the dynamics between frequenters as well as their relationship with the stadium's architecture. Thus, they include the manner in which fans enter the stadium, how they divide themselves and remain there, the dynamics of the flags, the way the fans yell, jump and experience emotions and since all this produces a representation of space and place, it deserves our attention in this study.

Understanding the dynamics of socialization and the use of large sports structures with their multiple meanings helps to delve into the perception of the importance that competition, the game, and its nuances hold in a people's culture. Thus, in diverse regions of this planet, soccer carries with it the idiosyncrasies, peculiarities, and traditions of a nation, making this sports phenomenon one of the planet's largest cultural goods.

After the methodological decisions, this study was structured in three sections. In the first, we introduce the two elite informants with life trajectories that are strongly associated with Maracanã, which justifies the reason they chose to work as they do. Afterward, there is the data analysis section, which is divided into two moments (from 1950 to 2000 and from 2000 to 2010). Finally, we finish the study with our final considerations.

\section{Methods}

In order to analyze the data, we used document analysis combined with the interviews based on the fundaments of oral history. For Meihy ${ }^{7}$, oral history is made of a series of procedures that begin with the construction of a project and continue with the definition of a group of individuals to be interviewed with the help of a script/plan for the recordings and future transcription with the confirmation of the testimonials. The author also points out that this method has many advantages, as oral resources are rich in details and facilitate the understanding of subjective facts that might be obscured in a written version due to the greater rigidity usually found in texts, especially official ones. Also, oral history can cover different themes, giving a voice to those who are normally silenced or those who have different or unofficial opinions about occurrences related to the study object. It also emphasizes that information fills in empty spaces and blanks in document sources, complementing them with the richness of oral evidence. Oral history searches for the truth within someone who witnessed an event or has disputable data or a different version of events. It also interests us as it admits the use of a questionnaire or a guided interview to clear up information that is contained in the analyzed documents. Thompson ${ }^{8}$ emphasizes that oral history has the peculiarity of transforming study objects into subjects, unlike traditional history, where historians study the actors of history from a distance, always subjecting it to the historian's own interpretation.

We opted to edit the interviewees' contributions, especially in the questions related to Maracanã and the symbolism that were developed in the stadium. Both gave us information about the construction of the stadium and its transformation into to a sacred place for sport. The analysis of the testimonials and documents allows for the identification and interpretation of the fans' experiences in the stadium as a place for soccer in Rio de Janeiro.

The two interviewees were chosen for having made and maintained themselves as people of notorious knowledge regarding the sporting activities and the history of the edification of Maracanã and its adaptations. Both are icons of the splendor of the stadium, representing and synthesizing the effective appropriation processes of this place. Given their qualifications, their testimonials, herein edited and analyzed, offer a panchronic vision of the stadium's symbolism. In an in-depth interview, according to Thiollent ${ }^{9}$, we can take the affirmations of the only notorious interviewee on the subject as a reference. Both interviewees experienced the stadium from its inauguration until games stopped happening in 2010 when the stadium was closed in order to be restructured for the 2014 World Cup.

Based on the edition of these two interviews, we reconstructed the atmosphere of some important moments in the stadium's trajectory. The memories are social, based on $\mathrm{Sá}^{10}$, as constructions of the present about experiences and memories of the past and give access to the different forms of use and interpretation of the stadium by the fans ${ }^{8}$. The same idea is reinforced by Goellner"1 (p.200): "Although the memory may be guarded by an individual and have his experiences as a reference, this memory is marked by the social group in which this individual participated and socialized". In this interpretative context, we postulate that our specialized informants represent the collective subject about the architectonic and symbolic aspects of Maracanã, rescuing and preserving remains and memories of practices and behaviors.

Alongside the interviews, we used data of a documental nature, retrieved from research done in the archives given to us by the Rio de Janeiro State Sports Superintendency (SUDERJ), 
which give us relevant data about the stadium's structure, as well as its relations with the fans. Documental research is characterized by the use of specific materials such as databases, magazines, reports, letters, photographs, newspaper articles, recordings, videos, websites, slides or other documents that have not yet undergone analytic treatment, always directed towards supplying evidence and/or justification that sustains the research proposals. ${ }^{12}$

Veyne ${ }^{13}$ explains that an occurrence only makes sense inside a series. The number of series is indefinite and they do not follow a geometric pattern in which logic can be used to completely elucidate the occurrence. We believe that the combination of methodological tools such as oral history/specialized interviews and documental analysis can afford us a more approximate vision of the phenomenon which is our study object. The interviews associated with the documents bring our findings closer to the truth, avoiding the possibility of only having words from the past as our sources by reconstructing them from the future. In the same way, only having the "cold" data from the documents can only show us the official history, which is not necessarily factual.

The notion of history is an inaccessible frontier. It is relative and reflects the intention of our values in the answers to the questions that we decide to ask. To describe the totality of facts in the historical field would be an impossible task since a path must be chosen and it cannot meander everywhere. We also believe that none of these paths is the only one, or the right one, much less one that reflects on the totality of history. Thus, oral history articulated with documental analysis develops a more scientific version of the whole. History is in the set of information, in the crossroads of possible itineraries and especially in the proposed objectives ${ }^{11}$. This study was approved by the Ethics Committee in September of 2012 under protocol number CAAE: 07820112.7.0000.5287.

\section{About the Interviewees ${ }^{1}$}

The first one is a historical representation of the sports journalists who helped build the sportive imaginary of the stadium. The second interviewee is the son of the chief architect of Maracanã in 1950 and represents a generation that was taken to the stadium from infancy. This generation incorporates cultural, emotional and sporting values into the stadium itself. Both present a general overview of the stadium, through complementary points of view, that contribute to the construction of the grammar of the games in relation to the stadium. At the same time, these records register singular episodes and events that indicate fractures, variabilities, and differences between the actors who experienced the old Maracanã.

\section{Washington Rodrigues}

The in-depth interview was given by the sports journalist Washington Rodrigues (WR) happened in 2012 at his place of employment in the Radio Tupi headquarters in downtown Rio de Janeiro for approximately one hour. The narrative about
Maracanã justifies the fact that he was chosen as an informant of well-reputed journalistic knowledge about the history, changes, disruptions, and reorganization of spaces and the groups that passed through the stadium. His life story is intertwined with that of Maracanã.

He watched the placement of the stadium's foundation stone, and was and continues to be a journalist and critical commentator. He is nostalgic about the old stadium ${ }^{2}$, and has an empirically grounded discourse. In radio broadcasting, Washington interacted extensively with the fans, reaching 100,000 people by radio, provoking the fans, who responded in unison. He baptized and initiated fans with the terms Geraldinos and Arquibaldos ${ }^{3}$.

I would ditch class to watch the conclusion of
the construction work, I would walk around the
seating areas; I have been inside Maracanã since
the foundation stone was put in place and I went
to watch and from then on, the stadium became my
office; the championships in the 1950s, Flamengo's
tri-championship in '53, '54 and '55, I was an
Arquibaldo; in the Brazil x Paraguay game in the
elimination phase of the '58 World Cup, I was
already a reporter and I started to have to go to
all of the games. Afterward, in the 1980s, I became
a commentator.

WR writes the column Geraldinos and arquibaldos in the newspaper Meia Hora, where he describes everyday soccer with an ethnographic eye and contributes to the establishment of circulating ideas about soccer culture. He synthesizes the memories that were constructed and reconstructed and that stood out in the course of the stadium's history, as well as those memories that become denser in relation to the restructuring and renovations of the stadium. His memories synthesize the homogeneity of the discourse, and above all, the practices of the fans, therefore contributing to the preservation of sports experiences.

\section{Gregório Feldman}

The answers from the in-depth interview given by Gregorio Feldman (GF) in November of 2012 at his home in a twohour interview prove him to be a reputable respondent with his remarkable knowledge and his personal involvement that led him to act in the campaign for declaring the stadium a historic site.

Son of the chief architect of the stadium, GF incorporates in his memories his father's passion for soccer and the grandiose nature of the project. Surrounded during the interview by documents and sketches from his personal archives, he reveals a passionate relationship with Maracanã. The analysis that GF makes of the games and the episodes experienced there, enables him to recover the memories and social representations that circulated and still circulate in fan culture.

I would go to Maracanã two or three times a week; I would sit in the permanent chairs from 
when I was four or five years old; there were wonderful games that I was able to watch, such as the final game of the World Clubs Championship between Santos and Milan, Brazil's classification for the 1970 World Cup, the Brazil x Paraguay final, which apparently hold the record for the most fans and Flamengo losing to Bangu at the end of the Carioca Championship $3 \times 0$-there was a nasty fight. The image that calls my attention the most was the Fla $x$ Flu, the emotion was indescribable: the colors, the rice powder, Flamengo's fans (...)

The respondents differ in focus. The journalist, fan and sports commentator looks outside with an analytical eye and is enchanted by what he sees. The doctor, both a fan and ethnographer, sees himself as a passionate fan and sees how he forms and consolidates in himself the passion for the stadium and its fans.

The discussion of the issues of the interviews allows us to infer that Maracanã occupies a privileged place of entertainment and leisure in Carioca imagination. It is a point of reference for the emotions of sport, an architectural monument that the fans are proud of. It is a space that was transformed into a place of celebration, parties, happiness, and movement. It is a house of sports, which hosts those who are passionate about them.

\section{Results}

The narrative part, from 1950 to 2010 , is separated into two parts: from 1950 to 2000 and from 2000 to 2010, with references to the importance of each period. Such a division is owed to the fact that from its inauguration to the year 2000, Maracanã hadn't undergone any significant structural modifications. In 2000, thanks to the World Interclubs Championship, the General sector was closed and metallic dividers were placed in the seating area. In 2007, another intervention completely ended the existence of the General sector which had chairs installed until 2010, when the stadium was closed for the big changes that happened due to the 2014 World Cup.

\section{From the unknown to the familiar: from 1950 to 2000}

The location that was chosen for the construction of the future Maracanã (at the time the Municipal Stadium of the City of Rio de Janeiro) was the Derby Club terrain, a turf club that was founded in $1885^{13}$. To get the work started, the Third Battalion of the Armed Forces had to vacate the area and the deposit of remaining World War II material had to be transferred to another Army location.

When the location of the stadium was determined, the extent and quality of access had to be taken into account. The region where the Derby was located was well-served by railway lines, which facilitated access to almost two-thirds of Rio's population at that time. ${ }^{14}$
The initial construction process involved the gestation of the proposals, the discussions, and the detailing of the project before finally arriving at the architectural work. The need for the country to have a stadium came from the 1950 World Cup, which would be hosted in Brazil and that made it necessary for there to be a stadium with the capacity and structure to receive the event. According to Gaffney ${ }^{1}$, "the stadium symbolized Brazilian passion for the sport and highlighted the role of architectural monuments in the communication of political and sports ideologies" (p.29). For the author, the whole stadium carries in its structure political and social messages, whether through the choice of location or through the architectural shape or even through the norms and criteria that were established.

It was in this context that the Maracanã Stadium emerged as a "sports space" constructed in a location without any reference to soccer until that moment. It would initially be a "space" for people who don't have familiarity or even affection for it. However, for the fans for whom it established connections and sportive experiences, the stadium was transformed into a symbolic place, a sports temple. It fulfilled the function predicted by Tuan (p.114):

Completing a building or complex architecture, becomes, therefore, an environment capable of affecting the people that stay in it [...]; the constructed environment defines the functions and the relations [...]; the architecture is the key to understand the reality. ${ }^{3}$

However, the environment can be capable but not necessarily effective. The significant architectural works for a group to become preferred places while for other groups, they are simply space. As Mascarenhas ${ }^{5}$ (p.6) writes, "the big stadiums, for instance, are planned in order to facilitate the large flow of spectators on days of important events, when the long silence of the concrete structures gives way to the crowd's delirium". Thus, at the same time that it is a party, it is also chaos, blocking the traffic, attracting crowds to its vicinity and provoking in some a feeling of topophobia.

On June 16, 1950, the official opening ceremony showed the world the soccer stadium. The ceremony was reserved for illustrious people. The following day it was the population's turn, for whom the stadium was a cause of local and national pride.

Maracanã's construction, as a monumental building and a maker of national architecture, exceeded the minimum criteria stipulated by the commission responsible for the initial project. It provided a closed stadium with a perfectly shaped curve ellipse and public movement by means of ramps. The profile of the parabola in the stands balances the view, and the minimum capacity allowed for 120,000 seated spectators and 30,000 standing (SUDERJ archives).

The imposing nature of the stadium justifies the account of the architect, which is marked by enchantment and surprise for the capacity of access to and from the stadium, with references to colossal works of other times. 


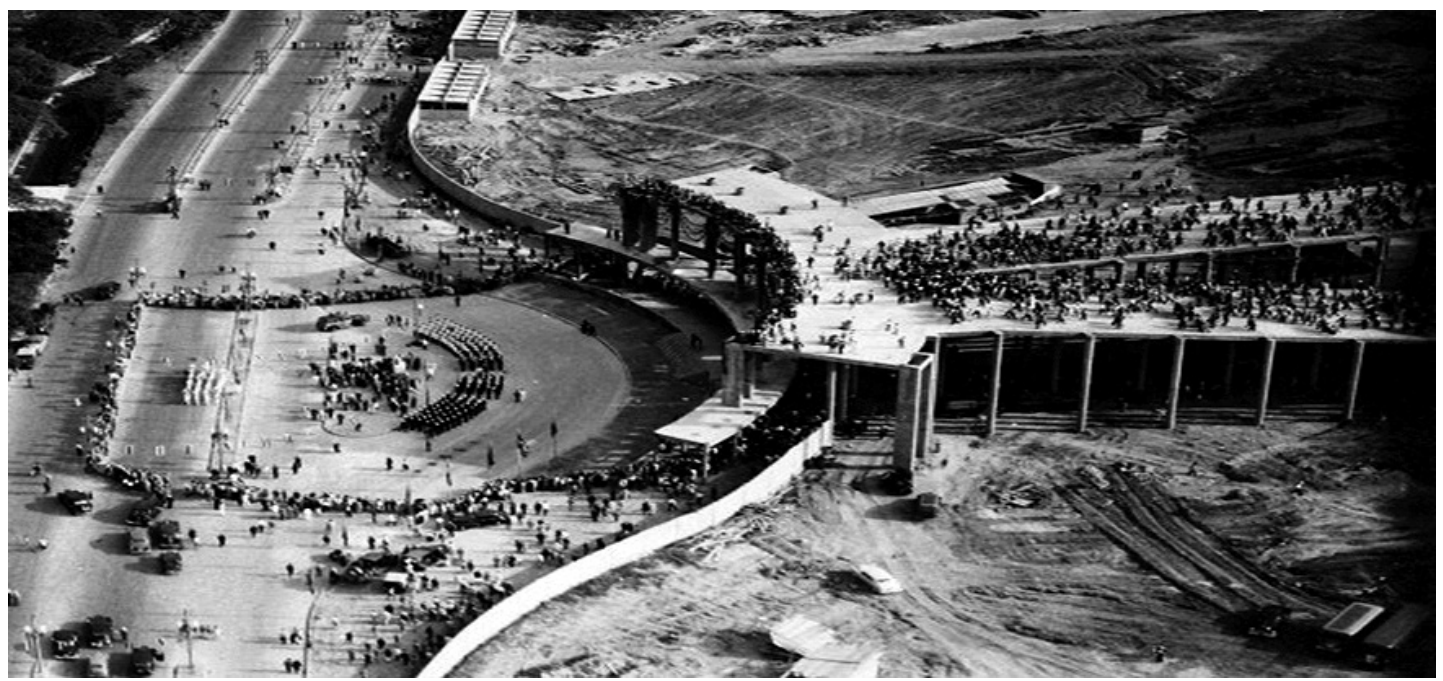

Figure 1.

It was a public competition. Only a person who understood a lot about soccer could construct a stadium like Maracanã and my father knew everything about soccer, aside from being a brilliant architect; when the project was conceived in 1947, he was 23 years old; the project was completed just as he had conceived it, with the entrance and exit ramps, revolutionary, the coverage system without pillars, it was a revolutionary work of architecture; the ramp, I think the inspiration came from the Coliseum in Rome. The idea was to make the entrance and the exit more secure, and not only with the ramps. The tunnels, those accesses you see in the Coliseum, were there in order for there to be water so the fans could not invade the arena; you had to keep the public at a distance. If you look at a photo of the Coliseum, you will see that there are many similar points, the tunnels are similar, the seating areas are similar.

The reference to the Coliseum, which inspired the ellipse shape of the stadium, indicates that the interviewee shares the typical feelings of affection for Maracanã, a symbol of the creativity and imagination of Brazilian architecture. Thus, the stadium follows Tuan ${ }^{2}$ in the sense that "the space constructed by man can improve the feelings and perceptions of humans" (p. 114). Contrasting aspects such as vertical/horizontal, interior/ exterior, closed/open, and public/private architectural space, there are experiences that people feel, becoming more intense and clear when in reference to a monumental work. Aside from defining sensations, the architecture of the stadium establishes social relationships, providing individuals with the consolidation of behaviors and values. Such experiences help construct meanings about the place. The vertical/horizontal dimension refers to grandiose structures such as the pyramids of Egypt, in which the monumentality emerges, independently of the work's aesthetic. According to Tuan ${ }^{2}$, these constructions assist the knowledge about mass/volume, and about the horizontal/vertical dimensions-therefore showing a contrast of power and rest.
The stadium, upon inauguration, could receive the public in all three sections. The first one, aimed at viewers in general who watched the game standing, included 35,000 people, (the geraldinos), and access to this area was supplied by four tunnels. The second section was reached by eight ramps and contained seats for 30,000, and 300 boxes that held five people each. The third section composed the stands above the seats and included space for 88,500 people. In the central part of this section, in the minor axis, there was a section of honor with 101 seats, the press section with 438 seats, a sports section with 200 seats, and the special section with 3,284, where the permanent seats were located. These were acquired by supporters upon payment of a value that contributed to financing the construction. Below this area, there were 20 radio and TV booths, and access to this section was achieved by way of three elevators and a staircase (SUDERJ file). Despite all this segmentation, both informants show us passages about Maracanã's democratic character. Fans from different social classes felt united by the feelings/emotions they underwent in the stadium.

To enter Maracanã and see that full stadium, like a color, a vibration, and the guy who paid one real could watch the game just the same as the President, though obviously in a different place. The geraldinos only paid one real to watch the game. (GF)

The cathedratic, the general and the geraldino. All three would swear at the referee in the same manner. When their team lost, they would want to pick a fight all the same and when they returned home, they were from different social classes. soccer levels things out. They swear, fight, sing... especially because the permanent seats, for instance, were right here and right after that railing the bleacher section started, so they were very close. (WR)

Each section had restrooms and bars. Under the grandstand, the stadium had room for 130 athletes, as well as restaurants 
and medical facilities. Four tunnels gave access to the field: one for referees, two for the teams and one for the police and journalists. The structure also provided parking, facilities for manufacturing its own ice and ice cream and for the installation of billboards, and other facilities (SUDERJ).

Work on the Maracanã Stadium began in 1947, 1948 and never ended. It's always undergoing some sort of construction work. To give you an idea, the reflectors at Maracanã were never conceived to be extended along the overhang (...).

The Maracanã Magazine was a free publication, launched by the stadium administration in the late 1950s and distributed to fans on game days. A few years later this magazine confirmed that the work was not completed effectively, and released a report with the following call: "Will we finish the stadium? Let's give Maracanã the finery it deserves!"16 The magazine showed that ten years after its inauguration, with the structural portion completed, the stadium needed finishing. The magazine, based on European models, was a pioneer in South America. It aimed to clarify and disseminate facts related to the stadium and sports events. The idea was to connect with the fans and help them become partners and conserve the stadium as a part of their society's heritage in order to build a relationship of mutual caring and belonging between the public and the stadium.

Supporters keep this publication, send it to your friend in any part of Brazil or the world. Show them the Maracanã Stadium, and show them how a great game day is a wonderful souvenir. But above all, begin with us the conservation and care of your, of our stadium. ${ }^{17}$ (p. 5)

Significant experiences allow for the establishment of effective places. Through the experiences of each game within an establishment where, according to Tuan ${ }^{3}$, individuals are away from outside distractions, common feelings are established and consolidated, exercising a great impact on these individuals.

There were four entrances to the stadium. Two gave access to the stands, one gave access to the blue seats in the tribunal sections, the special seats and radio and TV cabins, and the last gave access to the general sector. Access to the stands was through ramps situated in opposite positions that resulted in heavy circulation around the stadium. The first entrance to the stands was at Maracanã Avenue, known as the "Bellini Entrance" -- this was because of the presence of a statue, right in front of the entrance, that represented the moment when the defender Hilderaldo Bellini, captain of the Brazilian team in the 1958 World Cup, lifted the Jules Rimet cup. The monument ${ }^{4}$ is a point of reference as a meeting place for fans where people await the arrival of friends and families.

The next entry to the stands hitherto referred to as the "Skeleton Ramp", came to be known as the UERJ Entrance, due to its proximity to the campus of the State University of Rio de Janeiro. It was exactly in front of the ramp to the Maracanã subway station, and just a few meters from the train stations in the area. Since the cheering fans usually stayed in the bleachers, these two entries were used as concentration points of cheer group members. There they began to prepare their "arsenal" with musical instruments and flags. In the classic days, the fans that stayed in the stands used predetermined entrances due to security reasons. This designation of space was a consequence of the violence that arose within the cheering sections.

The third entrance served as an access for special sections (tribunes, permanent seats and radio and television cabins, and for the blue seats. It was called "Gate 18 Entrance". Located on Professor Eurico Rabello street, one of the stadium's lateral streets, it was used by supporters of both teams, whether in uniform or not. It functioned less as a meeting place for fans and more as an access to the interior of the stadium. Finally, the fourth entrance gave access to the general section, by Radial Oeste Avenue. It was the most popular access with the cheapest tickets, where people had to remain standing.

Past the turnstiles, ramps and piers revealed the grandeur of the space to the fans. In the inner ring of the stadium, the fans circulated freely, and the organized cheer groups were in their rooms preparing for the grand entrance with the flags and the bass drums, where they could reveal their power before the rival cheering section.

You would enter Maracanã on a Fla-Flu game day, with almost two hundred thousand people and there were all those colors. On one side, the Flamengo fans and on the other, those of Fluminense, with the general section filled to capacity. To enter Maracanã and see that stadium as one color, one vibration $(G F)$

What is beautiful in Maracanã? The cheering sections partying; it's taking the elevator to the sixth floor and when you open the door, there it is, a full Maracanã. (WR)

For Vertinsky and Bale ${ }^{6}$, the best way of creating a consciousness and a memory about an event or a place is through the different ways in which the fans experience a certain reality. And this experience, for the authors, is afforded by the five senses (sight, hearing, touch, smell, and taste) that are specific to each place; in our case, each stadium. With this, our interviewees show us that the vision of the full stands when entering Maracanã, of the flags, the team colors and the deafening noise of the songs and yells of the fans help to construct the feelings and memories of the place; in our case, Maracanã.

The creation of the Flag Room changed the fortunes of cheering groups, who no longer needed to carry so many large flags on the trains and buses. It reinforced the imaginary of "house of sport", where they kept the necessary equipment for celebration and "war". These rooms allowed the construction of a sense of belonging for the cheering groups because the groups for each team had their own place in the stadium.

The territory of the stadium was divided and organized with a team's own provinces for each match. Inside, the division of the spaces to watch the games followed the financial ability of 
the fans. The best places were situated in central spaces of the stands in relation to the field. At the bottom, as we said, was the section for geraldinos, with no seats. Right behind them were the cabins, which no longer had the same prestige as in the initial period of the Stadium because they did not provide adequate visibility of the field.

In the general sector, the people watched the game while standing, having a greater ease to move freely, though with an impaired vision of the field. This was the "folk" section, where fans watched the games in costume.

There are incredible geraldinos, see? So those types, there were many in Maracana and I specialized in covering these people. There was one gentleman who, in the São Cristóvão game, would position himself right in front of the center line in the general section, with a newspaper under his arm and his little batteryoperated radio. There was another, Gerdau, whom I dubbed "the general section's yell", since he thought he directed the team. So he'd stay in the middle and when the team went out when Flamengo attacked, he would accompany the team in their attack, telling them to do this and do that and so on. (WR)

The spectacle began with the entrance of players onto the field, a moment in which the fans began the ritual of receiving the team. This included, among other things, the waving of huge flags, balloons filling the air; at nighttime games, they used signal lights that gave a special color to the celebration. Many fans stood, singing the club anthem and other songs. While the players warmed up on the field, the cheering sections shouted their names, and the players reciprocated by waving to the fans. During the games, they cheered, yelled and celebrated but also complained and harassed the actions of their rivals and sometimes of their own teams. After scoring a goal, they all hugged each other to celebrate. There was a lot of happiness in the spectacle, especially for the victorious team. The deafening noise conveyed the size and strength of the fans, taking them near the action.

At the end of the game, the fans left the place quickly. If happy, they sang; if frustrated, they left silently. The organized cheering groups, however, followed the same pattern of a demonstration of force, singing songs whose lyrics emphasized their power. Besides their music, the ways in which they left -pushing, jumping, united in groups --also indicated the symbolic clash that existed inside the stadium.

Despite the mass movement, the experiences that are established with the place are individual and, according to Tuan $(\text { p.151) })^{3}$, "we are not even aware of them [...] because they are difficult to express". But to become aware of them shows evidence of strong emotion. The experiences bring comfort and lifelong affection. Through daily happenings, the fans establish their relationships with Maracanã, whether through accompanying their team at every game or through experiencing classic games and deciding matches. These experiences produce intense emotions.

I have been inside Maracanã ever since the first stone was laid. That is to say: when the started to build Maracanã, I studied at the Lafayette Institute on Haddock Lobo street and I would skip school to see the construction being finished, I would walk in the stands and the security guard would kick us out... then on the day when the foundation stone was set, I went to watch and from then on, the stadium became my office (WR)

I grew up inside Maracanã. I had a very happy childhood, the big moments with my Dad, I think I spent the largest part of my time with my Dad in Maracanã in 25-year partnership. It was a party going and a party coming back and I loved it and it could be a weekday and it was always like that, a marvelous getaway and I would dream 'aw man, it's ending, there's school tomorrow' (GF)

Soccer, with its plays, goals, and celebrations, marks the fans and gives them a pause in the day-to-day movement, in which the stadium becomes a center of recognized value for them. It turns into a place where they can take care of necessities such as leisure, socialization, and catharsis. In addition to the architecture and experiences, time is also punctuated as a way to acquire experience with a place. ${ }^{3}$

The ways in which fans use Maracanã changed as time passed (consequences as much of social and cultural patterns of each epoch as of modifications in the physical structure of the stadium) and reflect new pressures and challenges of social configurations. For Elias, the interdependent relationship between people created a movement and instituted a social order that establishes historical changes and alterations in the uses and customs of a society. These are denominated by the author as a civilizing process. This process, which alters the social patterns and institutes different practices and behaviors of the individuals, requires the passing of years and is responsible for providing diverse experiences..$^{18}$

The clothing used at the beginning of the Stadium's history gave way to less cluttered sportswear, reflexes of the alterations in the fans' social patterns. In addition to the changes in the dynamics of the clothing, some changes also appeared in the use of the stadium. Fans had previously brought pillows in order to avoid sitting directly on the concrete stands, but today they sit in comfortable chairs. The hand-held cell transistor radio is another example of a custom that disappeared, in addition to the cold and hard concrete of the stands.

In the big games, such as Flamengo $x$ Vasco, there were around 150 to 160 thousand spectators and people would sit in the top bleachers, in the bottom bleachers, lie down in the middle, people would go from lap to lap as though they were sacks of beans until they found a place to sit. (WR)

Sometimes it was so full, there weren't electronic turnstiles, just a slip of paper, that you couldn'treally leave your seat because you would lose it, even if you were in a permanent chair, you sometimes had to sit on the concrete. My father would take his 
battery-operated radio. People liked it and it was funny because it was actually huge and we would huddle together to listen to it right inside Maracanã... The announcer was the one with the final word, best place. There was no television, no big screen... (GF)

These practices change as a function of time and a reflex of the social configuration, and also of the spatial structure of the stadium, light and beautiful, that helps establish certain behaviors. The organized cheering went through phases as a consequence of these factors. Our journalist informant comments that:

\begin{abstract}
As practically every Carioca team had a unique organized cheer, as an announcer I could encourage practices that fed the party atmosphere inside the stadium. I would make a prize for the best cheer, the liveliest, the most beautiful, and I could get a cheer to circle throughout the whole inner ring of the stadium, and give a bouquet of flowers to the opponent fans, showing unity and respect between the fans (interviewee WR).
\end{abstract}

It was the spirit of reconciliation, of fair play, and of the social cohesion caused by the sport. The "topofilia"19, partially suggested by the architecture, shows that the affections for a place thrive and become symbolic. In these places, things happen those mark individuals and create important meaning for them. For Mello "they are emotional ties woven over the years" and because of this the place becomes like a dear and special "loved one". At the same time, in their absence or remodeling, discontentment can surge as if we had lost part of our sporting history. ${ }^{20}$

\section{Altering the familiar: from the year 2000}

After 50 years of continued use of the stadium, the deterioration of the physical structure and the consciousness of the non-functional aspects of it were visible; modernity brought adjustments that generated discussions over whether to demolish or renovate it, whether to privatize it or not. The stadiums that would receive world events needed to adapt to the FIFA standards.

For the First World Clubs Championship, organized by FIFA in the year 2000, the stadium was obligated to offer more comfort and security to fans. The renovations were the first big alteration, mostly visible in the grandstands section, that received seats along its entire length. The grandstands became segmented, with bars that kept fans from circulating inside the ring, especially to control violence.

The price of tickets for the grandstand began to be differentiated, and what continued to define prices was visibility. The white chairs, more expensive, were in a central position in relation to the lawn, facing the tribunes and the special chairs. In this section, opposing fans stayed in harmony. The rest of the grandstand was divided in yellow and green seats, and the price was the same for those. This alteration wouldn't allow the fans to trade sides anymore, passing through the grandstand, and not even the organized cheer groups could parade with their flags through the whole length intended for their team.

The cabins passed through the superior ring of the stadium above the grandstand; separated by glass, they offered comfort never experienced by the fans. In this new era, the private companies began to enter the stadium, selecting areas for their invited VIPS. The stadium's capacity was reduced to 103.000 places.

When the city of Rio de Janeiro won the right to host the Pan American Games in 2007, there was another restructuring. The stadium was closed from 2005-2007 and the structural alterations included even the lawn, which was lowered 39 inches in order to favor the visibility. In this renovation, the alterations were more drastic and were felt especially by the fans of lower income levels. The strongest alteration was the extinction of the general section, thus giving way to the section of blue chairs. Maracanã's capacity was again reduced, this time to around 87,000 fans. Changing rooms, bathrooms, bars and press boxes were also modernized for the event. ${ }^{21,22}$

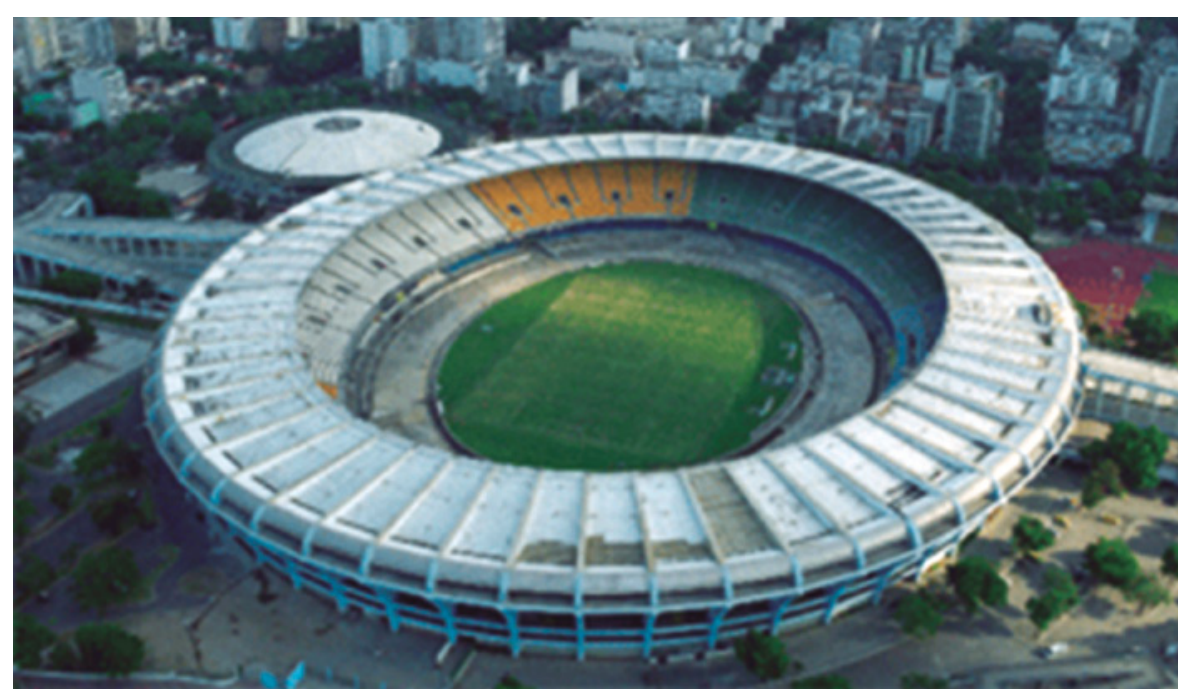

Figure 2 . 
In 2010, the stadium underwent a new heavy restructuring, which kept only the original frontage, a landmark of the National Historical and Artistic Heritage Institute. ${ }^{23}$ To host the 2014 World Cup, the modernization followed international standards. The stadium joined the list of the most modern in the world, fulfilling FIFA requirements. It's worth remembering that according to $\mathrm{Damo}^{24}$, the World Cup is much more than a soccer competition. Within the event, we can also find the consumption, profits for both the federation and the stakeholders and from this combination, we can distinguish two groups, antagonists in their interests. On one side, this economic power put towards the event and modernity and on the other side, resistance groups that fight for the economically challenged people who are directly affected by the changes that are necessary to bring about an event of this size.

The implementation of the new project resulted in a deep "ressemantization" of the stadium. Alongside the enthusiasm for the new features and functions of the stadium, the new settings brought about feelings of melancholy and longing for the stadium's glorious past, as well as feelings of uncertainty regarding the new, more modern and comfortable equipment. As interviewee GF states, "I think that it's a democratic space that will be very difficult to get back". WR states that

I think Maracanã is over. It's another stadium now. We'll call it Maracanã and all, but that magic, that thing, I think it's done. Now it will be something else, another stadium with another culture. I think that a lot of its romanticism will be lost. (WR)
In Maracanã, where the importance of places to the fans was marked by specific entry gates, by the places previously stipulated by the grandstands, and by hymns and war cries, moving the games to another stadium during the refurbishment of the equipment led to the disruption of identity and ties of belonging, given that "symbols emerge from the direct experience, transmitted by other people or at least worshipped in dreams; some are transient, others permanent"25 (p.174).

For Gaffney and Mascarenhas ${ }^{26}$, the changes required by FIFA propose a prison-type stadium, governed by severe rules that control all aspects of the sporting spectacle, from entry to exit from a game, as the authors mention

All seated, no carnival, rallies or things of the sort. The clubs accept it because the new consumers, besides being much better "behaved" (they don't interfere with the game), also bring more money to the ticket offices and passively consume products within the stadium. (p.09)

With this restructuring, Maracanã allows for new practices/ behaviors and representations, and the symbolic character of the stadium will be responsible for establishing connections between the past and the present. About the future and the new proposed configuration, our informant synthesizes and corroborates the aforementioned authors, pointing out was it expected from the stadium and showing a rupture with the initial idea from Maracanã's construction in 1950: a space of leisure for the populace:

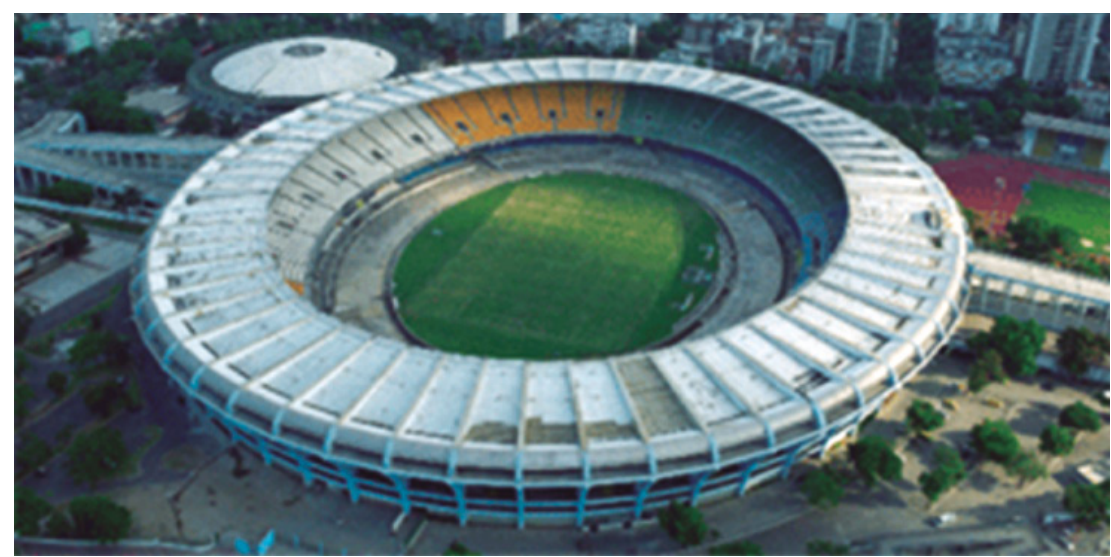

Figure 3.

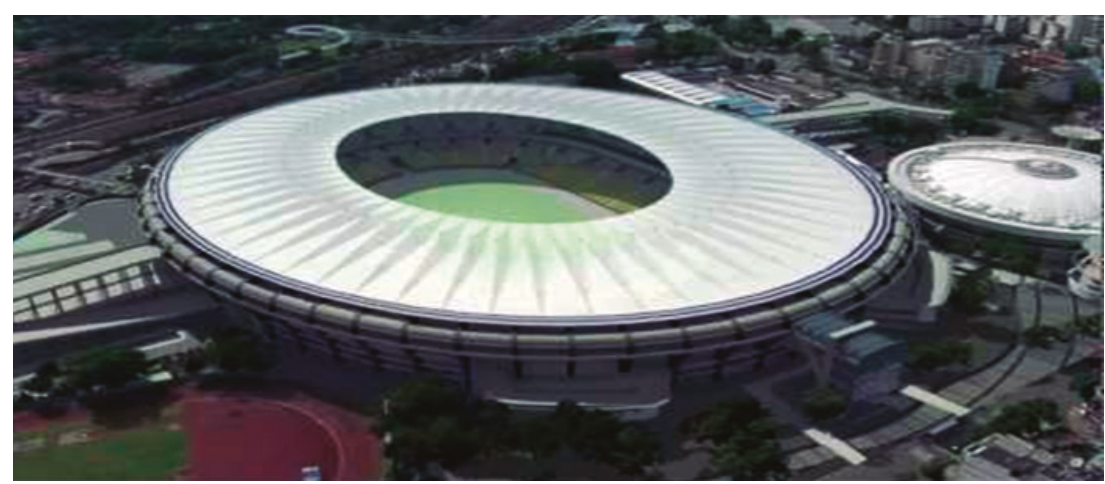

Figure 4. 
The fun of going to Maracanã will be expensive. The idea is to be able to create a new public, one that is already educated for that. (WR)

Now it'll be elite. They've gotten rid of soccer's democratic characteristics and it's a pity since, in the name of FIFA's rules, they've ended the magic. They don't think of other things aside from profit. They ruined a monument. Poor people will never watch soccer again.

\section{Conclusion}

Maracanã is a prototypical example of a place of fun, entertainment, leisure, and joy. To be there represents a pause in the movement of day-to-day life, and this constitutes and marks a "place", "a center of recognized value". It is a cozy and sacred place and provides experiences, sensations, and natural feelings. Through the stadium's architecture, the experiences in the inside, and the passing of 60 years, people establish experiences and, from these experiences, understand the significance of "being in" and of "being with"3 (p.153).

The moments, lived by fans that frequent Maracanã, comprise the defeats and victories of their teams and also the Brazilian national team. The meetings of families and friends provide intense emotions, ingredients of the construction of the stadium's symbolism.

Considering the transformations that happened in Maracanã stadium, and considering the sports mega-event of the 2014 World Cup in Rio de Janeiro, we can predict that significant changes will take places in individual-space relations and habits. However, according to Connerton, that does not signify the disappearance of these habits, but a journey to the place of memory. ${ }^{27}$ The relations that surge with the new Maracanã are constructed from different pasts, lived by individuals. Scenarios of different times, described in this study, show that the relationship between fans and the stadium changes with time and also contributes to the new relationship webs that make Maracanã a new place in line with the current sport trends. The empirical aspects, which are innovative from the point of view of the subject's role in the midst of a discursive community, are sufficiently strong in the construction of arguments. The data indicate a set of perceptions and social representations, described by the informants of esteemed knowledge about the stadium. The concepts of space and place help us to understand the locus of the generation of popular knowledge, related to a regionalized building structure, which expands, through imagination, to the minds and hearts of people, regardless of geosportive dimension.

Tuan's postulation ${ }^{3}$ contributes to the explanation of Maracana's basic forms of appropriation. The binary formulation (space/place) represents a point of departure in a multiple configurations in which polar terms should be considered as points of a continuum in whose route the social actors that make up the different groups of fans are positioned. The analysis of the position of these subgroups is a subject for further studies.

This study shows that the public that frequented the stadium presents relatively consistent and predictable ways of relating to a place. When trying to understand the experiences lived by the fans of Maracanã, one must play a role in establishing reference and anchoring points. The vicissitudes of each subgroup are lightly illustrated in the singularities present in the discourse of the two informants and can be investigated in studies about each organized cheering group, or about other groups that form the basis of any point of identification.

Every city has places, such as Maracanã, which are immortalized in societal memory, where reconstitution and restoration are also responsible for access to their souls ${ }^{4}$. The understanding of the fascination exerted by the stadium passes through all forms of knowledge, rituals and practices that happened there. In conclusion, we conceive the 'old' Maracanã as a place of memory. It falls to us to simulate where we stopped time so that the experiences that were undergone in that place until that moment are not forgotten since, according to $\operatorname{Nora}^{28}$ (p.22), the fundamental meaning of these places is to "immortalize death, materialize the immaterial".

The architecture, as we accept the postulate of its disjunctive character ${ }^{29}$, points to ruptures and dissensions between the functionalist propositions of a stadium that, on one side, serves the interests of spectators and guarantees their safety and integrity and, on the other, contemplates the security procedures in order to maintain and contain the fans, avoiding contact between fans of different teams both inside and immediately outside the stadium. Functional architecture is, by assumption, a work of art and is thus partially detached from immediate functionality. Rearrangements, productively speaking, are not always in favor of the public and can very often go against its wishes, such as when security issues are addressed. The disjunctive character is also verified on the topographic plain. The stage is in the center of the stadium, which is functional. However, the relationship with the sun creates a dilemma and constitutes an unsurpassable obstacle for most of the spectators on sunny afternoons.

Thus, we admit that the fractures of the past and the memory disputes of the present in Maracanã's reconstruction deserve investigation. We hope to cover this subject in new incursions on the theme, which is apparently infinite. We further suggest that more research be done in other parts of the world that have the privilege of having such emblematic stadiums, true sports temples and that this research be shared/published in order to amplify the knowledge of the most varied forms of sports culture, facilitating the recognition of sport's importance in contemporary society.

\section{Endnotes}

${ }^{1}$ After choosing the possible informants, we contacted Radio Tupi, Washington Rodrigues' place of employment and the interview was promptly scheduled. The other informant, Gregório Feldman, was suggested to us later and when we made contact, he was very solicitous towards us

${ }^{2}$ When mentioning the old Maracanã, we are considering the period of 
time going up to 2010, while the new Maracanã's time period starts in 2013, after the large restructuring the stadium underwent between 2010 and 2013 in order to receive the 2014 World Cup games. At that point, we observe a completely reformulated inner space, in conformity with the demands of the Fédération Internationale de soccer Association (FIFA).

${ }^{3}$ Name given to the fans who watched the games from the General and Bleachers sections.

${ }^{4}$ The name of the statue is not a consensus. For more information, visit http://globoesporte.globo.com/bau-do-esporte/noticia/2014/03/ estatua-do-bellini-homenagem-ao-eterno-capitao-tem-muitas-versoes.html Access: Oct. 7th, 2017.

\section{References}

1. Gaffney C. Megaeventos e dinâmicas sócio-espaciais no rio de janeiro, 1919-2016. Revista Brasileira de Estudos do Lazer. 2016; 3(3): 23-45.

2. Tuan YF. Geografia humanística. In: Perspectivas da geografia. São Paulo, DIFEL; 1982. 143-63.

3. Tuan YF. Espaço e lugar: a perspectiva da experiência. São Paulo, DIFEL; 1983.

4. Mello JB. Explosões e centralidades no Rio de Janeiro. In: Espaço e cultura, Rio de Janeiro, UERJ/NEPEC; 1995. 23-44.

5. Mascarenhas G. A Geografia dos esportes. Uma introdução. Revista electrônica de Geografia y Ciencias sociales. 1999; 35. Available from: $<$ http://www.ub.es/geocrit/sn-35.htm.> accessed: 13 mar 2010.

6. Vertinsky P, Bale J. Sites of sport: space, place, experience. London and New York, Routledge; 2004.

7. Meihy JCSB. Manual de História Oral. São Paulo, Editora Loyola; 1996.

8. Thompson P. A voz do passado: História Oral. Rio de Janeiro, Paz e Terra; 1992.

9. Thiollent M. Metodologia da Pesquisa-ação. 2nd Ed. São Paulo, Cortez; 1986.

10. Sá CP. Sobre o campo de estudo da memória social: uma perspectiva psicossocial. Psicol. Refl. Crít. 2007; 20(2), 289-94.

11. Goellner, SV. Informação e documentação em esporte, educação física e lazer: o papel pedagógico do centro de memória do esporte. RBHCS. 2006; 25(1), 199-207.

12. Sá - Silva JR, Almeida CD, Guindani JF. (2009). Pesquisa documental: pistas teóricas e metodológicas. RBHCS. 2009; 1.

13. Veyne P. Como se escreve a história. Brasília, Editora UNB; 1998.

14. Melo VA. Cidade sportiva: primórdios do esporte no Rio de Janeiro. Rio de Janeiro, Relume Dumará; 2001.

15. Sergio R. Maracanã, 50 anos de glória. Rio de Janeiro, Ediouro; 2000.
16. Vamos terminar o estádio? Revista do Maracanã. Rio de Janeiro; 1960. p.1-7.

17. Revista do Maracanã. Rio de Janeiro; 1959. p.5.

18. Elias N. O processo civilizador: uma história dos costumes. Rio de Janeiro, Jorge Zahar Ed; 1990.

19. Tuan YF. Topofilia: um estudo da percepção, atitudes e valores do meio ambiente. São Paulo, DIFEL; 1980.

20. Mello JB. Símbolos dos lugares, dos espaços e dos "deslugares". In: Espaço e cultura, Rio de Janeiro, UERJ/NEPEC; 2008b. p.167-74.

21. Vieira C. Maracanã: templo dos deuses brasileiros. Rio de Janeiro, C. Vieira; 2000.

22. Bueno E, Máximo J, Assef R, Castro R. Maracanã 60 anos: 19502010. Porto Alegre, Buenas Ideias; 2010.

23. Iphan. Instituto do Patrimônio Histórico e Artístico Nacional. (2000). Available from: $<$ http://portal.iphan.gov.br/portal/montarDetalheConteudo.do? $\mathrm{id}=15951 \&$ sigla $=$ Noticia\&retorno=detalheNoticia $>$ Accessed: 01 may. 2012.

24. Damo AS. O direito, o desejo e o dever - a trama que trouxe a Copa para o Brasil. Movimento. 2012; 18(2): 41-81.

25. Mello JB. O Rio dos símbolos oficiais e vernaculares. In: Espaço e cultura: pluralidade temática. Rio de Janeiro, EDUERJ; 2008a. p.173-86.

26. Gaffney G, Mascarenhas G. O estádio de futebol e o espaço disciplinar. Seminário internacional Michel Foucault-perspectivas. Universidade Santa Catarina. 24 set, 2004, p.09.

27. Connerton P. Como as sociedades recordam. Oeiras, Cela Editora; 1999.

28. Nora P. Entre memória e história: a problemática dos lugares. In: Projeto história: revista de projetos de estudos pós-graduados em história do Departamento de História. 1993; 10, p.7-29.

29. Biesta G. Para além da aprendizagem. Belo Horizonte, Autêntica; 2013.

\section{Corresponding author}

Silvio de Cassio Costa Telles Mail address: Rua Campos Sales, 81. apt 201. Tijuca. Rio de Janeiro, RJ. CEP: 20270-214

E-mail: telles.ntg@terra.com.br

Manuscript received on May 14, 2018

Manuscript accepted on August 23, 2018

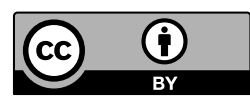

Motriz. The Journal of Physical Education. UNESP. Rio Claro, SP, Brazil - eISSN: 1980-6574 - under a license Creative Commons - Version 3.0 